\title{
Article
}

\section{Dark open innovation in a criminal organizational context: the case of Madoff's Ponzi fraud}

Manning, Paul, Stokes, Peter, Visser, Max, Rowland, Caroline and Yedidia, T. Shlomo

Available at http://clok.uclan.ac.uk/22310/

Manning, Paul, Stokes, Peter, Visser, Max, Rowland, Caroline and Yedidia, T. Shlomo (2018) Dark open innovation in a criminal organizational context: the case of Madoff's Ponzi fraud. Management Decision, 56 (6). pp. 1445-1462. ISSN 0025-1747

It is advisable to refer to the publisher's version if you intend to cite from the work. http://dx.doi.org/10.1108/md-05-2017-0535

For more information about UCLan's research in this area go to http://www.uclan.ac.uk/researchgroups/ and search for <name of research Group>.

For information about Research generally at UCLan please go to http://www.uclan.ac.uk/research/

All outputs in CLoK are protected by Intellectual Property Rights law, including Copyright law. Copyright, IPR and Moral Rights for the works on this site are retained by the individual authors and/or other copyright owners. Terms and conditions for use of this material are defined in the policies page.

\section{CLoK}

Central Lancashire online Knowledge www.clok.uclan.ac.uk

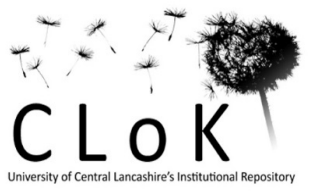




\title{
Dark Open Innovation in a Criminal Organizational Context:
}

\author{
the Case of Madoff's Ponzi Fraud
}

\begin{abstract}
Purpose

This paper investigates the processes of open innovation in the context of a fraudulent organization and, using the infamous Bernie L. Madoff Investment Securities (BLMIS) fraud case, introduces and elaborates upon the concept of dark open innovation. The paper's conceptual framework is drawn from social capital theory, which is grounded on the socio-economics of Bourdieu, Coleman and Putnam and is employed in order to make sense of the processes that occur within dark open innovation.
\end{abstract}

\section{Design/methodology/approach}

Given the self-evident access issues, this paper is necessarily based on archival and secondary sources taken from the court records of Madoff $v$ New York-including victim impact statements, the defendant's Plea Allocution, and academic and journalistic commentaries - which enable the identification of the processes involved in dark open innovation. Significantly, this paper also represents an important inter-disciplinary collaboration between academic scholars variously informed by business and history subject domains.

\section{Findings}

Although almost invariably cast as a positive process, innovation can also be evidenced as a negative or dark force. This is particularly relevant in open innovation contexts, which often call for the creation of extended trust and close relationships. This paper outlines a case of dark open innovation.

\section{Research limitations/implications}

A key implication of this study is that organizational innovation is not automatically synonymous with human flourishing or progress. This paper challenges the automatic assumption of innovation being positive and introduces the notion of dark open innovation. Although this is accomplished by means of an in-depth single case, the findings have the potential to resonate in a wide spectrum of situations.

\section{Practical implications}

Innovation is a concept that applies across a range of organization and management domains. Criminals also innovate; thus, the paper provides valuable insights into the organizational innovation processes especially involved in relation to dark open innovation contexts.

\section{Social implications}

It is important to develop and fully understand the possible wider meanings of innovation and also to recognise that innovation-particularly dark open innovation-does not always create progress. The Caveat Emptor warning is still relevant.

\section{Originality/value}

The paper introduces the novel notion of dark open innovation.

Keywords: Dark Open Innovation, Social Capital, Ponzi/Affinity Fraud. 


\section{Introduction}

Innovation, which broadly involves the facilitation and generation of, inter alia, new ideas, products, and markets (Marques, 2014), has-both historically and conventionally-been cast as beneficial and positive for both individuals and organizations. In this vein, many definitions and variations of innovation have been developed in recent decades (Johannessen, Olsen and Lumpkin; 2001; Christensen, Scott, and Roth, 2013; Hedström and Wennberg, 2016). The extant literature readily acknowledges that nurturing and engendering innovation presents challenges and difficulties, including: wasted energy and materials, misguided energy, and over-zealous or poorly understood 'disruptive innovation' (Markides, 2006; Hung and Chou, 2013). However, the overall positive couching and general desirability of the concept and notion of innovation obscures its darker side (Molina-Morales, MartínezFernández \& Torlò, 2011). The argument of this paper is that there is scope to view innovation as an ambivalent concept; one that can be understood as either facilitating positive outcomes - as evidenced in the extant literature - or as being negative and malignant. In consequence, innovation needs not only to be understood as having the potential to be creative and progressive, but also to be acknowledged as dark, destructive and regressive in a manner that has far reaching impacts; for instance, disruptive innovation.

To this end, this paper expands the notion of open innovation by proposing and extending it to encompass the new concept of 'dark (open) innovation'. It does do by analysing a recent egregious example of destructive financial innovation: the BLMIS Ponzi/affinity scandal (Zuckoff, 2005). The corrupt BLMIS organization was synonymous with its founder and chief executive Bernie Lionel Madoff; the analytical lens of this study thus focusses on the innovative processes by which he negatively created a toxic and criminal culture that facilitated one of the largest financial frauds in the history of capitalism. This paper develops the view that there is a robust connection between human dynamics and innovation; for example, the instance of intangible assets being integral to 'roping' investors into sharing investment opportunities. In consequence, this article will examine how Madoff built up his intangible assets, including his reputation, as an essential component of his fraud. As this is an important and understudied topic, the development of a greater awareness and understanding of dark open innovation processes is vital for management practitioners to avoid being drawn into similar compromising situations. Such knowledge can enable 
practitioner audiences to better protect and nurture both their personal and organizational assets and reputations. This leads to the following research question:

How do processes of 'dark open innovation', as a form of open innovation, operate and what are the implications for organizations and management practitioners?

This paper proceeds as follows. It first elaborates upon the notion of open innovation, introducing and developing the concept of dark open innovation. It then outlines its methodological approach and presents the Madoff's Ponzi/affinity fraud as an example of dark open innovation. It concludes by proceeding to analyse how Madoff expertly used his acute insights into human dynamics in order to create a criminally focussed network the assets of which, such as trust and reputation, were used to entice his investors and victims. Madoff's sentencing transcript, which-together with their related documents and commentaries - provide the sole data available on this case, are an archival source of information on how the investors viewed their enticement into this dark open innovation system.

\section{Literature Review}

Marques (2014) broadly defined innovation as: "[an] on-going process of learning, looking, and investigating, which results in new items, new strategies, new types of association and new markets". Moreover, Anderson, Potočnik, and Zhou (2014:4) pointed at the role played by the creative dimension of innovation and suggested that "Creativity and innovation at work are the process, outcomes, and products of attempts to develop and introduce new and improved ways of doing things." In recent decades, the debate has widened to incorporate 'closed' and 'open' innovation (Worsnop, Miraglia and Davies, 2016). 'Closed innovation' represents the conventional and earlier view of innovation in which the related research and innovative activities were conducted primarily within a given organization and the resulting expertise and resources-together with the knowledge products and outputs-remained proprietorial to that organization. In the globalized and radically transforming world of shared technologies and ideas, the sustainability of this approach has been questioned and the way pointed towards a more 'open orientation' (Chesbrough, 2003). Felin and Zenger (2014:1) described open innovation as follows: 
"Open innovation scholars have focused on the need for focal organizations to transcend their boundaries by sourcing knowledge and technology externally ... The notion of open innovation has encompassed a wide range of external actors, including users, customers, suppliers, universities, and competitors. The underlying mechanisms for accessing external knowledge and fostering open innovation have, in turn, encompassed a range of alternatives including contests and tournaments, alliances and joint ventures, corporate venture capital, licensing, open source platforms, and participation in various development communities."

Natalicchio et al. (2017) recently conducted a systematic literature review and, by adopting a knowledge management lens, distinguished the three main open innovation processes-i.e., inbound, outbound, and coupled; in doing so, they set an agenda for future research directions. The introductory comments show that Madoff's fraud was likely to comprise all three elements, which heightens the complexity of the phenomenon of dark open innovation. Unlike most previous studies, which had examined the performance effects of open innovation on high-tech and large enterprises, the study conducted by Wang, Guo \& Yin (2017) focussed on the antecedents of open innovation strategies in high- and low-tech, large and small firms; their findings reveal that different forms of organizational slack divergently influence corporate open innovation strategies, thus enhancing our understanding of the relationship between organizational slack and knowledge search behaviours in a broader context, and providing a better comprehension of the moderating effects of absorptive capacity (Wang, Guo \& Yin, 2017). Interestingly, Martinez-Conesa, Soto-Acosta \& Carayannis (2017) showed that information technologysupported operations and commitment-based human resource practices generally have a positive and significant influence on knowledge management capabilities. However, their findings did not provide corroborative evidence in relation to the relationship between interdepartmental connectedness and knowledge management capability, whereas both the latter and environmental dynamism have a direct influence on open innovation - thus being potential factors in the case under consideration. Furthermore, Miglietta, Battisti \& Garcia-Perez (2018) investigated the potential relationship between shareholder value and open innovation, and particularly highlighted the fact that, by adopting different open innovation practices, US-listed companies can create more value for shareholders in the long term while, at the same time, beating the market. In a slightly 
differing vein and by addressing the management of knowledge via intellectual property rights from the individual (personal), project and company levels, Bican, Guderian \& Ringbeck (2017) viewed the process of open innovation beyond its normative modus operandi, considering the preparations for, and termination of, its related activities. In this vein, and appropriately for the Madoff milieu, Casprini et al. (2017) found a link between the rather underexplored topic of open innovation and the family business context. They did so by means of an empirically grounded model that illustrates how the idiosyncratic capabilities of a family-owned firm can help overcome the critical barriers to obtaining and disseminating knowledge while pursuing an open innovation strategy.

Thus, while the extant work has generated valuable observations, overall, the notion and practice of open innovation have been generally cast in a positive light. However, an emergent strand of literature has more assertively considered what is termed the 'dark side' of innovation (Gravier \& Swartz, 2009; He \& Tian, 2013; Molina-Morales, Martínez-Fernández $\&$ Torlò, 2011). This 'dark side' runs counter to the general positive account of innovation suggested in much of the literature and points at the dysfunctional aspects found in innovation processes; these, for example, include the manner in which innovation projects can place staff under additional pressure, engender failure in innovation partnerships due to over-optimism, rhetoric, and mistrust, or undermine the embedded ties between suppliers and customer, which can impede customer innovation knowledge (Noordhoff et al, 2011). The dark side of innovation is particularly striking in open innovation contexts. While much research has been conducted in relation to varying contexts and communities in which open innovation commonly occurs - i.e., teamwork, leadership, creative and social media (Dictoff, 2015; Gatzweiler, Blazevic \& Piller, 2017; Saleh \& Hu, 2016) - the financial arena and, in particular, acts of fraud committed in that domain have been relatively under-researched. There is thus scope to consider these dimensions in a more granular fashion as they have major impacts on, and implications for, markets, economic sectors, and also society in general.

The above discussion also shows that innovation commonly involves a range of relations that are grounded in various forms of social capital, which concerns the relationships that occur between individuals and between individuals and organizations linked to the creation of actions and value (Hitt and Ireland, 2002). In particular, social capital theory points at those resources that are not necessarily available to people by means of acquisition or inheritance, 
but rather through their connection with other individuals (Lin. 2001). Therefore, networking is, in many forms - including innovation processes - key to the creation of capital, (Anderson, 2010:3; Dess and Shaw, 2001).

As a body of thought, social capital evolved during the early $20^{\text {th }}$ century and has come to be viewed as a means of countering the societal divisions brought about by neo-liberal capitalism and marketization (Baker 2012). Epistemologically, social capital is associated with three established theorists: Bourdieu, who took a Marxist perspective and demonstrated how notions such as 'honourability and respectability' provide opportunities to accumulate capital (Bourdieu, 1985); Coleman, who looked at the drivers in education and nurturing found in family life rather than in class (Field, 2003); and Putnam, who, building on, and reacting to, earlier work, focussed more on communitarian-as opposed to individualactions in building social capital: "social networks, and the norms of reciprocity and trustworthiness that arise from them" (Putnam, 2000:19). In particular, Putnam identified bonding capital- "inward looking [networks that] tend to reinforce exclusive identities and homogeneous groups" (Putnam, 2000: 22)—and bridging capital_-"outward looking and encompass people across diverse social cleavages" (Putnam 2000:22). He stated that, whereas bonding capital works like 'superglue', bridging capital works as 'WD40' (i.e., an unlocking/lubricant oil) (Putnam 2000:23). As will be seen in the discussion below, social capital resonates considerably with the processes and dynamics that underpin open innovation-and, as in the particular case under consideration, the dark open innovation involved in Madoff's Ponzi scheme-and is therefore employed as the over-arching conceptual framework for the argument below.

Moreover, historical contextualization needs to be provided in addition to the social and cultural fabric surrounding (dark) innovation. The general positive and progressive (as opposed to dark) casting of innovation can be seen as having deep social and historical roots which can be traced back to, for example, the 'Whig view' of history and progress derived from the British political movements of the seventeenth and eighteenth centuries and the emergence of the Enlightenment (Stokes, 2016). The Whig view of history, that sees things 'getting better', has been challenged in modern historiography to the extent that the term 'Whig' is now mainly used in a pejorative acception (Carr, 1985:55). In business and management, however, the untrammelled optimistic Whig interpretation is still evident, with the dark side of contemporary concepts tending to receive far less attention than its usually 
well-researched positive one. For example, Brenkhert observed that the drawbacks of entrepreneurship are under-discussed and he detailed the common motivational roots shared by entrepreneurs, criminals, and juvenile delinquents. He also noted deception, manipulation, and authoritarianism as unedifying behaviours, frequently exhibited by entrepreneurs, which tend to be omitted in the largely positive conceptual literature (2002:6). Innovation is perhaps a case in point also in the fact that open innovation is purported as an inevitable, inexorable, and, in many regards, positive force. In the light of the changes brought about by globalization - swift technological exchanges and advancements, capital transfers, market expansion, and wealth generation (Baldwin, 2016) - open innovation appears as an inevitable and appropriate corollary. Collaborating, sharing risks and costs, accessing the best knowledge available (wherever it may reside, either within or outside a firm) are central tenets of open innovation approaches. However, they also present risks. Operating in such networks and in these manners also requires faith, trust, and confidence in the integrity and bona fide nature of the efforts and activities being undertaken (Sol, Beers, and Wals, 2013; Mathews and Stokes, 2013). In those instances in which this essential aspect or 'glue' is absent, situations become prone to dark open innovation. Thus, 'dark open innovation' can be understood as an act (or acts), idea, product, or arrangement that, by appearing encouraging and beneficial (based on perceived trust), seems to offer positive opportunities to the parties involved, but is ultimately likely to cause substantial harm and damage. This is because this form of innovation lacks 'good faith', is disingenuous, has a weak basis of trust and may even be grounded on a deceitful or criminal premise. Dark open innovation ultimately denigrates and destroys value rather than augmenting it. The next stage of this paper develops the methodology and empirical case used in order to explore the issue of dark open innovation.

\section{Methodology}

The paper employs a qualitative approach (Denzin \& Lincoln, 2011; Silverman, 2011). The data were developed through a case construction of the Madoff Ponzi fraud (Edmondson \& McManus, 2007; Eisenhardt \& Graebner, 2007). Fraud is usually classified within a subdivision of criminology, termed white-collar crime or corporate crimes of the powerful (Newburn, 2007). Furthermore, the fraud domain is notoriously challenging to examine because of litigious and reporting constraints as well the occasional dangers that might arise when approaching and engaging with a criminal research area (Payne, 2012:4-19). Therefore, 
the data were necessarily drawn from, inter alia: court reports, subsequent enquiries, academic articles, trial reports, and journalistic analyses and commentaries. The purpose of victim impact statements is to enable victims to personalize and detail the impact of a crime, which is termed therapeutic justice (Cassell and Eraz, 2011). In the case under examinationUnited States V Bernard L. Madoff_-167 substantial statements were submitted; out of these, the prosecution chose to submit 113 substantial statements, with nine victims permitted to speak at the sentencing trial. The statements therefore comprise the views of only a fraction of the defrauded. For example, financial institutions, which suffered the biggest losses-e.g., Banco Santander (US\$2.87 billion) and Bank Medici (US\$2.1 billion) —as well as charities and celebrity investors did not submit any statements, perhaps to avoid negative publicity. For example, Lewis (2012) concluded that a common response to being defrauded is a state of denial, while Perry and Brody (2011:35-38) also discussed the difficulties of responding to "a betrayal of trust". The statements, which are therefore unrepresentative per se, are nevertheless valuable for their role in 'shaping the Madoff narrative' in the sphere of public opinion. One can also speculate that the statements articulated the views shared by other BLMIS investors; three themes relating to human dynamics and facilitating criminal innovation can be identified through them.

The research was observant of issues linked to structuring the data within the case presentation (Gioia, Corley \& Hamilton, 2013). This approach responds to Siggelkow (2007), who signalled the need to accompany in-depth cases with secondary supporting and triangulating data drawn from various documentary sources. The analytical approach adopted a template analysis (King \& Horrocks, 2010) structuring, which, within the overall conceptual framework, enabled the emergence of themes and sub-themes from the archive and documentary sources. The reliability of the account was reinforced by the reading of materials with independent coding and subsequent convergent authorial team coding.

\section{Dark Open Innovation: Background to the Bernie Madoff Case}

“Had the stock market in the US not collapsed, Madoff's scam would probably have continued" (Arvedlund, 2009:263).

Bernie Madoff's parents, Ralph and Zara, ran a small brokerage firm that was investigated by the Securities Exchange Commission (SEC) for failing to submit financial documents (Nars, 
2009:194). Their son followed in the family trade, founding Bernard L. Madoff Investment Securities (BLMIS) in 1960. He later claimed that he had earned his initial investment stake by working as a lifeguard at city beaches. This sort of anecdote was typical of the disarming storytelling approaches used to build trust across an open innovation setting. In the early 1960s, Madoff concentrated on making markets for small parcels of bonds. His ambition was to expand BLMIS so that he could enter the more lucrative trading equities market. An important observation in this regard is that the process of dark open innovation started from relatively small beginnings and then grew incrementally. In a cautionary fashion, this underlines the importance of spotting dark open innovation (as opposed to more positive open innovation) at the earliest possible time.

At first, BLMIS struggled to attract clients and Madoff focussed_his energy on exploiting his familial and friendship and religious/ethnic ties, as his: “... early investment clients were friends and relatives in the New York Jewish Community" (Arvedlund, 2009:25). Madoff, who was an expert at inspiring trust, charmed his way via his family ties into the acquaintance of retired attorneys, teachers, and other professionals who started to invest in his supposedly 'conservative' investment fund. The fund then started to develop rapidly when wealthy accountant Sol Alpern began spreading the word on Madoff's ability to provide excellent returns. Alpern, however, had failed to mention to his wealthy clients that, by making successful introductions, he too stood to benefit from the business (Ibid:25-28). In criminology terminology, Madoff was following an affinity fraud operating strategy, which refers to investment scams that prey upon members of identifiable groups (networks), such as racially, religiously, and ethnically defined communities, the elderly, and professional groups, or other groups likely to engender forms of open innovation sharing and mutual support. Furthermore, the fraudsters who promote affinity scams frequently are-or pretend to bemembers of the groups they target (Perri and Brody, 2011:34). This is an approach typically adopted by financial criminals, who prey on their own communities by exploiting trust-based interactions, as researched by Ventura and Daniel, (2010), who noted the prevalence of religious affinity frauds, and by Perri and Brody (2011), who investigated church-based affinity based frauds. From a dark open innovation perspective, it is interesting to note the role played by 'corollary advocates' - in the case under examination, Alpern, who spread 'good news' reports regarding Madoff's highly innovative and successful work. The potency of such championing of innovation was underscored by Howell and Boies (2004); however, in the Madoff case, its potential negative downside is indicated. 
Madoff's firm prospered; in the early 1970s, he was credited with being one of the financial sector's IT innovators. This provoked hostility from those established brokers who did not like computerization and, according to Madoff, “... even had congressional hearings against $m e "$ (Gelles and Tett, FT, 2011). Despite such opposition, BLMIS continued to prosper and established itself as one of the largest independent trading operations in the securities industry. In 2000, at the height of the Internet bubble, BLMIS held around US\$300 million in assets and was ranked among the top trading and securities firms in the world. Driving this growth was Madoff's assiduous cultivation of his reputation, both as an innovator and as 'America's Financial Guru'. Madoff possessed entrepreneurial flair and even took the credit for the exploitation of computer technology to automate stock trading. He constructed an automated computer-based stock market that used the Cincinnati Stock Exchange License. The known leniency of the Cincinnati Stock Exchange rules may have been what attracted Madoff. It is also worth noting that the speed of technological change, which Madoff very much pioneered, posed challenges to the financial authorities, who found decentralized trading difficult to regulate or, perhaps, even to fully understand in terms of its potential to facilitate criminal activity (Arvedlund, 2009:40-44).

In promoting technology-based trading, Madoff also established himself as a vocal lobbyist for deregulation: he donated heavily to both the Democratic and Republican campaigns and sat on a number of committees advising on stock market restructuring, as well as acting as the chairman of NASDAQ. He was solidly building his bonded social capital (Putnam, 2000). It is also significant that Madoff operated a hedge fund (these funds were not required to register with the SEC until 2006, and hence were not subject to any regulatory scrutiny) (Arvedlund, 2009:151). Madoff therefore exploited technological innovations, as well as regulatory lacunae to promote his firm and his criminal activity. By doing so, he set up the antecedents for a (dark) open innovation environment in which he could operate. Technology is frequently viewed as a central and positive dimension of innovation and innovative environments (Hemlin et al, 2014). However, the Madoff case clearly demonstrates that technological innovation also involve complex dimensions that a range of audiences may find difficult to follow readily and are therefore also propitious for dark open innovation when people exchange and share through them. Furthermore, Madoff acted as an advisor to the SEC on market structure and other issues, which bolstered his carefully cultivated image of consummate professional insider. Madoff even encouraged marriage between his family and 
SEC members: his niece Shana married SEC staffer Eric Swanson, who was part of a commission team overseeing the planning of regulation pertaining to technological trading (Arvedlund, 2009:2011). Madoff's social capital with the SEC was such that he would claim that, every time a SEC investigator came to his office, he or she would make a job application (Lewis, 2012:73). Innovation clearly requires control and governance at various junctures (Van Oudheusden, 2014); however, Madoff's capacity for infiltrating and circumventing checks and balances through his dark open 'innovative' activities points at standard measures being clearly found to be wanting and to the need for a reflective and watchful series of safeguards.

Madoff claimed that the fraud began in the 1990s, but the investigators held that the roots of constructing the dark open innovation context actually extended back to the 1980s. Alternatively, a further, more plausible, judgment is that BLMIS was a fraudulent organization from its inception. The fraud's endurance and its innovation network, which was only exposed by the liquidity squeeze, can be explained with reference to a number of additional practices. First, Madoff cultivated a reputation for returning investments promptly; second, when the industry standard involved expensive investment fund fees, he charged very low commission; third, Madoff distributed lavish fees and commissions to feeder funds; and, fourth, his generous donations to charities created reputational capital to the point that it was hard to envisage this noted philanthropist to be anything but legitimate. Moreover, it is also little discussed and notable that not all investors lost money, as most took out more than they had invested (Nars, 2009:220). Thus, dark open innovation should not be considered to imply complete failure or value destruction (following Gauthier, 2014); at any rate, the Madoff case indicates that the overall picture might be variegated and questionable.

In the financial sector, Madoff was unique for the consistency of his returns and for his low fees, and some industry insiders had harboured doubts in regard to his operation long before the collapse of the firm. For example, in 1999, certified fraud examiner Harry Markopolos was asked by his employers, 'Rampart Investment Management', to reverse engineer Madoff's strategy to find out how he was winning their potential client's business. Markopolos claimed: "When I saw the return stream, I knew it was a fraud in five minutes." He also claimed it took him only 20 minutes to prove it: "His performance line went up at a 45-degree angle; that only exists in geometry class. It was clearly impossible." Another banker, Rob Picard, of the Royal Bank of Canada, reckoned it only took him 15 minutes 
talking to Madoff to realise it was all a fraud (Arvedlund, 2009:90). Nevertheless, Madoff continued to prosper despite Markopolos' best efforts to stop him, which included reporting his suspicions to the financial authorities:

“Countless times over eight-and-a-half years-meetings, written submissions, e-mails, phone calls. [What I provided] went from six red flags to 30 red flags, and any one of them was enough to stop Madoff."

Madoff recollected that "Markopolos was the biggest idiot in the world ... He had a hedge fund that couldn't make money and his clients abandoned him [so he called the regulators]" (Gelles and Tett: F/T 2011: April 8). But the regulators did not take action. "The regulators get calls all the time," Madoff said. They did not investigate "because I had the reputation at the time for being the gold standard. I had all the credibility. Nobody could believe at that time that I would do something like that. Why would I? Stupidity-that is why. But remember that, when people asked me about the strategy, it made sense. I was big, credible" (Gelles and Tett: F/T 2011: April 8). Madoff was convinced that he would be discovered on two occasions in 2003-4 and again in 2006. The SEC however, failed to check the basics, such as investigating his account with Wall Street's clearing Houses, and with the dealing firms that were supposedly handling his trades. It is also notable that BLMIS was mistrusted by industry insiders. Goldman Sachs, for example, would not put Madoff's fund on its approved list of intermediaries as his strategies would have required massive trading in stock options and derivatives, and none of their professionals had seen or heard of these trades. Credit Suisse also recommended its clients to withdraw their Madoff investments as it could not fathom how Madoff made its returns (Nars, 2009:212).

Madoff was sentenced to 150 years in jail. Despite his apology in court, Madoff remained unrepentant, holding fast to the view that his investors in the innovative network knew that his returns were too good to be true and thus were willing accomplices in his fraud. According to a fellow inmate, Madoff was also increasingly angry about his incarceration, stating, " $F^{* * *}$ my victims. I carried them for 20 years and now I'm doing 150 years" (Somaiya, Newsweek, 2010). 


\section{Dark Open Innovation and Human Relational Dynamics}

Human relational dynamics are central to the effecting of dark open innovation. The cautionary tale of Madoff highlights a range of warning signals (for dark open innovation) that need to be noted. Madoff purposefully targeted his own ethnic group in order to perpetrate his affinity fraud. Ethnicity is a concept defined with reference to language, religious, ancestral, and locational characteristics; the Madoffs both surrounded themselves with members of their own community, thus creating close proximity with those of a similar background who shared a sense of identification, which can be understood as "... the process whereby individuals see themselves as one with another person or group of people" (Nahapiet and Ghoshal, 1998:256). This is the typical approach taken by ethnic minority entrepreneurs, who will trade within a network based on common values and experiences, relying on the trust of a shared social network (Portes and Sensenbrenner, 1993). In social capital theory, similar insights are proposed by Putnam with regard to bonding capital (2000:362-3), Lin also points out that there tends to be a preference for homophilous interactions in networks (Lin, 1999:46-54). These observations are also detailed in Shibutani's, 'Reference Groups as Perspectives', a concept that notes that economic activity is often based on shared socio-cultural and religious values and characteristics (Shibutani, 1955:109). Madoff understood the importance of being embedded in an ethnic community: being identified as Jewish was not enough; he realized the necessity to be overtly embedded as a 'leading' and integral member of the community. This is a socio-economic insight, 'embeddedness' being first coined by Karl Polanyi, who argued that:

“... man's economy, as a rule is submerged in social relationships. He does not act to safeguard his individual interests in the possession of material goods; he acts so as to safeguard his social standing, his social claim, his social assets. He values material goods so far as they serve this end." (Polanyi, 1944/2001:60)

Madoff acted in accordance with these insights and, for instance, donated heavily to ethnic (Jewish) charities, became a member of the Board of trustees for Yeshiva University, and proclaimed his devotion to the Jewish religion and culture. Madoff was perceptive enough to recognize that charity, and, more generally, philanthropic activities enacted within his own community were a strong opportunity to develop his feeder networks. This approach fitted in 
with Madoff's preferred sales pitch of avoiding financial or 'capital introduction' parties, which would be full of financially savvy investors who would ask too many awkward questions. Instead, Madoff preferred to target fellow philanthropists by means of word of mouth recommendations and, together with other members of his family, he made a concerted effort to court the charity circuit, sitting on the boards of many charities and donating money to many others. This networking provided Madoff with two main paybacks. First, it gave him access to high society, which added lustre to his brand, making him more respectable and, consequently, credible. Second, it enabled him to market his products aggressively to gullible charity commissioners and, hence, provided a lucrative source of investors. The Madoffs' success lay in convincing charities to invest and be gauged by the reforms being planned to charitable foundations, altering their size and structure in order to decrease their reliance of 'personal ties' (Jagpal and Craig, 2009). In Hebrew, Madoff was described as a Shidduch - a matchmaker - and, in behavioural economics, both Ponzi and Madoff can be termed as 'connectors' (Gladwell, 2001:30-59). In network syntax, they cultivated 'weak' ties for 'brokerage benefits'. Madoff was a key agent within the dark open innovation network he and others had created both individually and collectively. Madoff also developed weak ties driven by a shared characteristic of highly developed 'people skills', which is consistent, for example, with trait theory in terms of social competency being a recurring quality or trait of entrepreneurs (Baron and Markman, 2003).

Madoff purposefully developed and innovated social capital weak ties to serve as recruitment networks. For example, Madoff was perceptive enough to realize no one was “... better to refer new clients than current satisfied clients" (Arvedlund, 2009:272-273). The fact that these agents usually took large commissions was kept secret from the investors and, as they brought clients into Madoff's fund, the agents also grew inordinately wealthy. To illustrate the recruitment network, it is worth noting that Robert Jaffe, a noted philanthropist like Madoff, 'worked' the 'Palm Beach Country Club' to the extent that over 30\% of its members eventually invested with Madoff. However, Jaffe failed to tell his 'golf buddies' about the commission he charged, or even about the fact that they were investing their funds with Madoff. In return for this deception, Jaffe became extremely wealthy, and the fraud continued apace. This deception also meant that a considerable number of investors in Madoff had had no idea that they were connected to the fraud until they received news that the Ponzi scheme had collapsed and that they had lost their investments. The degree of criminal complicity of Madoff's agents is open to question (some may have been innocent), though Madoff himself 
was in no doubt over their criminal culpability. For example, during his trial, he claimed that four of his earliest investors-Jeffry Picower, Stanley Chais, Norman Levy and Carl Shapiro - had helped recruit customers for his firm in the late 1980s, when Madoff was having difficulty unwinding positions in the markets; "They were complicit, all of them. Which is why they are all settling." (Gelles and Tett, 2011: $8^{\text {th }}$ April)

Madoff and his agents grasped that their frauds depended on them being accepted as upstanding members of their own communities, as these provided the bulk of the investors. This perception is consistent with Fukuyama's appreciation of culture in economic life, which concludes: "As Adam Smith well understood, economic life is deeply embedded in social life, and it cannot be understood apart from customs, morals, and habits of the society in which it occurs. In short, 'it cannot be divorced from culture"' (Fukuyama, 1995:13).

For this analysis, Burt's (2005) two level reputation generating hypotheses are most apt. The first 'bandwidth' hypothesis chimes with everyday assumptions by which actors own their reputations, in the sense that they define their behaviours, which, in turn define their reputations. For instance, Madoff cultivated a brand identity that was conservative, reassuring, and always immaculately presented: a committed family man and vigorous philanthropist who did not live an ostentatious lifestyle. Besides being well-established on Wall Street, the wider Madoff network members were also viewed as smart, educated, admired, and respected: pillars of their community and model Americans. The Madoffs were also noted for their conservative values and, paradoxically, were associated with low risk investment strategies; to his cautious investors, Madoff appeared anti-risk. Furthermore, although his returns were good, they remained within the realms of what a skilful and 'lucky' trader could achieve in a good year-8-12\% per annum-except for the fact that Madoff uniquely achieved these returns every year. Thus, the fraud was facilitated by Madoff's apparent conservatism, which gave him a persona that was the opposite of a 'get rich quick' one.

However, Madoff also exploited the processes described in Burt's second 'echo' hypothesis. In this hypothesis, reputation is not owned by an individual but, rather, by “... the people in whose conversations it is built, and the goal of those conversations is not accuracy so much as bonding between the speakers" (Burt, 2005:195). In consequence, "The key to establishing a good reputation is to get people in closed networks talking to one another", and, "Reputations do not emerge from good work directly so much as from colleagues' stories 
about the work ... the source of the reputation is stories third parties are telling one another" (ibid: 219-22). Herein reside important observations in relation to the way in which news of innovation is shared and disseminated. The Madoffs appeared to grasp that positive gossip was essential to maintaining their reputational assets as, from this perspective, reputation is dependent on an individual's freedom to make judgments; thus, reputation is transcendently motivated.

Madoff was admired and much talked about as the former chairman of the NASDAQ stock market, a friend of regulators, and vice-chairman of the National Association of Securities Dealers, his industry's self-regulatory body. He was also a role model in that he lived a gilded life, travelling with his family between a penthouse in New York and holiday homes in Palm Beach and Long Island, travelling in private jets and on his yacht. Madoff also understood the value of acts of kindness for spreading positive word of mouth, and consequently worked on his 'good guy' persona. For instance, in 2002, a rookie trader was seriously injured when he was hit by a car while training for the New York City marathon. "I passed out and woke up in the emergency room," the trader remembers. "[When I came to,] I looked to one side of my bed, and my mom and dad were there. On the other side was Bernie". Many employees 'loved' working for the Madoffs and most stayed with them right up until the fraud was revealed.

The Madoffs further enhanced their reputations by cultivating highly respected network ties that could serve as conduits to channel further victims into their fraud. In social capital literature, Lin noted that reputation is promoted by; “... recruiting actors with a reputation established elsewhere in society" (Lin 2001:154). Madoff fully understood the value of these network ties for facilitating his fraud; for example, he developed a close commercial relationship with Mike Engler, who ran a brokerage firm and, based on his exemplary war record, enjoyed high status in his suburban community. Engler convinced many veterans to invest with Madoff, and his military ties also served to draw in an extensive network of unsuspecting investors who, in turn, were connected to those veterans. To enhance his credibility and reputation, Ponzi had also made great play of his bank directorship of the hitherto respected Hanover Trust Company. 


\section{Dark Open Innovation and the Role of Trust}

An essential element for dark open innovation is the cultivation of relational trust (Möllering, 2006), on which investors rely instead of carrying out their due diligence. In social capital literature, it has been contended that levels of trust are related to levels of social capital (Adler and Kwon, 2002). For example, Fukuyama stressed the importance of trust and 'ingrained ethical habit' (1995) for 'lubricating' market-based transactions. Cohen and Prusak's view is also relevant:

"Trust is largely situational: a particular person may be quite trustworthy in one set of circumstances, but not in another, where particular pressures, temptations, fears, or confusion may make him unreliable." (2001:30)

As noted, Madoff further targeted high trust religious/ethnic settings and social structures. For instance, Madoff was skilled at targeting investors when they were at their most trusting; this was noted by Judge Chin, who admitted to being swayed in the severity of his sentence by a victim statement of a widow, who recalled that she had gone to see Madoff following her husband's heart attack. She recounted how Madoff had put his arm around her to express his condolences and said, "Don't worry; your money is safe with me". The widow subsequently lost all of her savings (Arvedlund, 2009:275). Madoff's technique was to interact or approach investors in non-financial settings, ingratiating himself in social and religious milieus; he knew that these environments fostered an ambience of trust in which investors would be more likely to see him as 'one of us' and, in consequence, let their financial guard down. These trusting environments included country clubs both in Palm Beach and the Hamptons and synagogues in Florida, New York, Minnesota, and Los Angeles (Arvedlund, 2009:26).

Madoff was also expert at gaining trust without giving up a lot of information. This is significant as high levels of trust and a culture of shared values facilitate white-collar crime. Conversely, in low-trust scenarios, transactions are scrutinized in detail and economic actors are wary of being cheated. Therefore, although high trust scenarios can create economic advantages - for instance, in terms of reduced transaction costs - at the same time, they provide opportunities for fraud. For example, Madoff followed a typical scam strategy in claiming to have privileged 'insider knowledge' based on connections. Thus Madoff was 
viewed as possessing exclusive bridging social capital (Putnam, 2000) or network brokerage opportunities that offered privileged investors access to highly lucrative investment opportunities. This, high levels of trust can be observed in the loyalty of Madoff's investors, with widows recounting how their deceased husbands had implored them "to never sell their Madoff holdings" (ibid: 50). What Granovetter noted from a social network perspective is also significant: that victim/offender relationships in financial scams are based on surprising levels of intimacy (Granovetter, 1992:43-44). In Madoff's case, it has been claimed that this intimacy extended to a shared set of beliefs. For example:

"To stay in Madoff' game, they agreed to cooperate with his deceptions. They honored his request to not talk about him or to tell others that he was managing their money. They didn't do due diligence." (Arvedlund, 2009:220)

One evaluation is that Madoff was able to cultivate trust-based relations to conceptualize his investors as his business friends. From this perspective, he cultivated work-based relationships as something less than social friendships, but more than purely economic transactional arrangements. Theoretically, this understanding is consistent with the Aristotelian-based interpretation that, “... business friendships are instances of incomplete friendships for utility"' (Schonsheck, 2000:897). Moreover, Aristotle assumed a hierarchy of friendships ranging from complete to incomplete; therefore, business friendships can be interpreted as "Incomplete friendships for utility ... [which] are not based on reciprocal love of character; the basis is reciprocal utility, reciprocal value" (ibid). Put another way, "In a utility friendship, a relationship is externally useful to both people". Translating this observation into the Madoffs' fraud, they offered investors the apparent opportunity for high returns and their investors, in turn, offered them willing victims.

A primary theme articulated within the court documents was an acute sense of Madoff's treachery, not only to individual investors, but more so to the wider community, as one investor stated,

"What Bernard L. Madoff did far transcends the loss of money. It involves his betrayal of the virtues of people hold dearest-love, friendship, trust-and all so he can eat at the finest restaurants, stay at the most luxurious resorts, and travel on yachts 
and private jets. He has truly earned his reputation for being the most despised person to in America today."

Affinity fraud can be interpreted as a 'hate crime' (Fairfax, 2003); one can speculate as to whether there was an element of self-loathing about Madoff, manifested in defrauding his own ethnic/religious community, or, more prosaically, whether he targeted this community out of mere opportunism. It is notable that Madoff never lost his outsider status - or his distinctive Lower East Side twang — among the wealthy Manhattan elite (Vanity Fair 2009). Thus, although he was part of the financial establishment-perhaps the ultimate insiderthere was a part of him that was perennially cast as the upstart from the wrong side of the tracks.

In overview, the trial statements constantly allude to a betrayal of community-based trust. A number of statements also draw attention to reports and commentaries that stereotype the investors (Lewis, 2012:46) as being interested in money; this is ironic, as it has been suggested that the fraud was facilitated by investors not conducting due diligence. The investors-“people who knew how to make money" (Perri and Brody, 2011:46) - were desperate to avoid living up to the negative stereotypes that were eventually reinforced when the fraud collapsed. Thus, there was a sense of betrayal of trust that was not confined to individual, ego-centric relations, but at the communal, socio-centric level. A key part of Madoff's BLMIS operations was to target his own community to exploit those ties that create trust, respect, and friendship, and that are usually considered an asset of such groups. This is a common approach both in affinity- and in religious-based frauds_(Perri and Brody, 2011; Ventura and Daniel, 2010). Madoff and his co-religionist associates targeted their own faith/ethnic community, thus creating close proximity with those, of a similar background, who shared a sense of identification, which can be understood as "... the process whereby individuals see themselves as one with another person or group of people" (Portes and Sensenbrenner, 1993). Madoff thus established his fraud based upon affinity, which also made it harder to detect. as "cautious skepticism is replaced by social banter" (Reed, 2007). Affinity frauds also tend to be more protracted than other types because of group cohesion: Perri and Brody (2011) also noted how social banter replaces due diligence. 
Of further relevance is Coleman's view that social capital is more likely to be created as an oppositional response "... where one type of actor is weaker in a relationship ... the actors of this type will be likely to develop social networks that have closure, in order to strengthen their position relative to the more powerful type of actor" (Coleman, 1990:319). Coleman analysed this bonding capital in social capital literature; he noted the robust religious and community bonds that enabled the Orthodox Jewish community to dominate the New York diamond trade due to the advantages of high levels of trust and consequent low transaction costs. The reverse side of this high trust context however, is that a skilful swindler-in part by emphasizing ethnic ties-could exploit this community resource. For example, the Madoffs stressed their allegiances to Jewish norms. Ruth Madoff, for example, had coauthored 'The Great Chefs of America Cook Kosher' (1996), and the family donated ostentatiously to Jewish charities and universities. Thus, although Madoff was described at his sentencing trial as 'an equal opportunities destroyer' the Jewish community suffered disproportionately.

'The effect on the American Jewish community was viral: 39\% of American Jews were affected in some way, either because an organization or charity they supported had been affected by the Madoff crimes (29\%) or because someone they knew had been affected (17\%)' (Arvedlund, 2009:25-26).

A second theme to emerge from the trial statements is the vehemence of the victim narrative, which is vituperative and 'ad hominem' in its focus. For example, "He's an economic terrorist". A third theme stresses that the victims had suffered losses of unimaginable magnitude. For instance, one victim stated that "It is impossible to compare this crime to any past criminal act". This is an attempt to shape the narrative away from the investors being greedy and complicit to being entirely innocent victims. Thus, the sub-text is that the investors refused to take any responsibility for what had happened to them in the con. This is a common investor reaction to the exposure of affinity fraud: a complete denial of culpability at any level. Conversely, Madoff remained convinced of his investors' shared culpability in the con. A consequence of this investor refusal to acknowledge any culpability was the consistent theme, in the victim statements, of blaming the SEC and other financial regulators for failing to identify and close down BLMIS, and implicitly to lay the grounds for appeals for recompense. 
"There are many levels of government complicity in this crime. The SEC, by its total incompetence and criminal negligence, has allowed this psychopath to steal from me and steal from the world".

This accusation, moreover, has validity; Madoff had developed close ties with the SEC by training its newly appointed lawyers in the hard-to-codify, context-specific insider knowledge of Wall Street, resulting in a tie relationship that (quid pro quo) screened him from the concentrated gaze of investigators. This theme of refusing to accept responsibility or any level of collaboration in the fraud contributed to the wider narrative of the investors being, above all else, victims who had been betrayed not only by Madoff, but also by the financial regulators, who had failed to discharge their regulatory duties. Hence, the authorities were in part culpable and therefore needed to recompense the investors/victims.

\section{Conclusion}

Dark open innovation requires the illusion of trust and confidence. The case examined above clearly underlines that it also often involves obfuscation through the use of poorly understood or complex technological systems. It is also possible to suggest that dark open innovation is easier to perpetrate in 'white collar' and service contexts, in which products are intangible and results and immediate consequences more difficult to glean or perceive than, for example, physical products. Nevertheless, building the necessary social capital and securing positions inside influential innovation strategy and policy bodies - even to the point of having relatives marrying into them - are imperative for the fraudster. Thus, dark open innovation frequently exploits close community or close circle ties and there is a need to be watchful of this. Bernie Madoff's exploitation of the New York Jewish community of which he was part is a prime example of this. With regard to further managerial implications, there is a need to develop alerting mechanisms, early warning signs, and invasive investigatory actions within closelyknit private and professional communities, the vulnerability of which to dark open innovation should be highlighted.

As a master at exploiting the dis-utilities of human dynamics, Madoff resembled many whitecollar fraudsters; hence, his crimes were predicated on sophisticated socio-economic insights into social interaction. The human dynamics perspective elaborated upon above complements 
the wider literature on, for example, criminology by examining crime's human factors and drawing attention to the resources that are inherent in the fraudsters' social interactions and structures in what remains the most heavily regulated industry in America. In consequence, this paper has challenged the propensity of the innovation literature to cast innovation as predominantly positive despite its noted setbacks and challenges. However, this paper has introduced the concept of dark open innovation and the potentially dangerous implications it has in relation to the social capital developed between individuals, managers, and organizations. The argument has sought to engage a range of literature sources by which to elaborate this notion and also to broaden and inform the overall literature on open innovation. By considering the recurring features of fraud from a social capital perspective, this paper has not only investigated the exploitative effects of social networks, but has also presented an expanded perspective that emphasizes the persistent human dynamic realities of social interaction in financial crime, such as Madoff's Ponzi scheme. A major implication for managers is to seek demonstrable substance in regard to exceptional performance indicators. Equally, where doubts and rumours have circulated, these should be subjected to serious consideration, rather than being discounted. Here, the everyday adages suited to capture this spirit could include "no smoke without fire" and "if it looks too good to be true...". This article has also examined the more qualitative embedded relational social realities within innovation networks and processes that are built up over time through reiterated interactions to create the social fabric of criminal network structures. From this perspective, this paper has demonstrated that innovation needs to move beyond its all-too-frequent orthodox soft, positive, and consensual view of benign capitalism to, rather, examine more closely how innovation processes are able to facilitate dis-utilities, such as white-collar crime. 


\section{References}

Adler, P. S., and Kwon, S-W. (2002), "Social capital: Prospects for a new concept." The Academy of Management Review, 27(1):17-40.

Anderson, L. E. (2010), Social Capital in Developing Democracies: Nicaragua and Argentina Compared, Cambridge, Cambridge University Press.

Anderson, N., Potočnik, K., and Zhou, J. (2014), Innovation and creativity in organizations: A state-of-the-science review, prospective commentary, and guiding framework. Journal of Management, 40(5):1297-1333.

Arvedlund, E. (2009), Madoff, The Man who Stole \$65 Billion, London, Penguin.

Baker, C. (2012), "Spiritual capital and economies of grace - refining the relationship between religion and the welfare state", Social Policy and Society, 11: 565-576.

Baldwin, R. (2016), The Great Convergence: Information Technology and the New Globalization, Boston, Harvard University Press.

Baron, R. A. and Markman, G.D. (2003), 'Beyond social capital: the role of entrepreneurs' social competence in their financial success'. Journal of Business Venturing, 18:41-61.

Bican, P. M., Guderian, C. C., and Ringbeck, A. (2017). Managing knowledge in open innovation processes: an intellectual property perspective. Journal of Knowledge Management, 21(6): 1384-1405.

Bourdieu, P. (1985), “The forms of capital.” In: J. G. Richardson (Ed) Handbook of Theory and Research for the Sociology of Education. Greenwood. New York, pp. 241-258.

Brenkert, G. (2002), "Entrepreneurship, ethics and the good society", in Ethics and Entrepreneurship. The Ruffin Series 3, Society for Business Ethics. Charlottesville, pp. 5-43.

Burt, R. S. (2005), Brokerage and Closure, Oxford, Oxford University Press.

Carr, E. H. (1985), What is History? London, Penguin.

Casprini, E., De Massis, A., Di Minin, A., Frattini, F., and Piccaluga, A. (2017), How family firms execute open innovation strategies: The Loccioni case. Journal of Knowledge Management, 21(6): 1459-1485.

Cassel, P.G. and Erez, E. (2011), "Victim impact statements and ancillary harm: The American perspective." Canadian Criminal Law Review, 15: 149-196.

Chesbrough, H. (2003), Open Innovation: The New Imperative For Creating And Profiting From Technology, Boston, Harvard Business School Press.

Christensen, S. and Roth, E.A. (2013), Seeing What's Next: Using the Theories of Innovation To Predict Industry Change, Boston, Harvard Business Press. 
Cohen, D. and Prusak, L. (2001), In Good Company. How Social Capital Makes Organizations Work, Boston, Harvard Business School Press.

Coleman, J. S. (1990), Foundations of Social Theory, Boston, Bellknap Press of Harvard University Press.

Coleman, J.S. (2000), "Social capital in the creation of human capital", in, Lesser, E.L. (Ed.), Knowledge and Social Capital: Foundations and Applications, Oxford, Butterworth and Heinemann. pp.17-41.

Cressey, D. R. (1973), Other People's Money, Patterson Smith, Montclair.

Denzin, N. and Lincoln, Y. (2011) The Sage Handbook of Qualitative Research, London, Sage Publications.

Dess, G. G. and Shaw, J. D. (2001), "Voluntary turnover, social capital and organizational performance", Academy of Management Review, 26: 446-444.

Dictoff, M. (2015), Storytelling at Work: How Moments of Truth on the Job Reveal the Real Business of Life, New York, Ideas Champions.

Economist. Fleecing the flock-The big business of swindling people who trust you $28^{\text {th }}$ January. Available at: http://www.economist.com/node/21543526. 2012.

Edmondson, A. C. and S. E. McManus (2007), Methodological Fit in Management Field Research. Academy of Management Review, 32(4): 1246-1264.

Eisenhardt, K. M. and Graebner, M. E. (2007), Theory building from case studies: Opportunities and challenges, Academy of Management Journal, 50(1): 25-32.

Fairfax, L, M. (2003), The Thin Line Between Love and Hate: Why Affinity-Based Securities and Investment Fraud Constitutes a Hate Crime. U C Davis Law Review, 36:10731100 .

Felin, T. and Zenger, T. R. (2014), Closed or open innovation? Problem solving and the governance choice. Research Policy, 43(5): 914-925.

Field, J. (2003), Social Capital, London: Routledge.

Fukuyama, F. (1995), Trust: The Social Virtues and the Creation of Prosperity, Simon Schuster \& Press, New York.

Fukuyama, F. (2001), "Social capital, civil society and development", Third World Quarterly, 22(1):7-20.

Gatzweiler, A., Blazevic, V., and Piller, F. T. (2017). Dark side or bright light: Destructive and constructive deviant content in consumer ideation contests. Journal of Product Innovation Management, 34(6): 772-789. 
Gauthier, C. (2014), Creating value while avoiding its destruction through R\&D management and innovation. $R \& D$ Management, 44(2): 171-172.

Gelles D. and Tett G. (2011), "From behind bars, Madoff spins his story', The Financial Times. April 8.

Gioia, D. A., Corley, K. G., and Hamilton, A. L. (2013), Seeking qualitative rigor in inductive research: Notes on the Gioia methodology. Organizational Research Methods, 16(1), pp. 15-31.

Gladwell, M. (2001), The Tipping Point, Abacus. London.

Granovetter, M. (1985), "Economic action and social structure: The problem of embeddedness", American Journal of Sociology, 91(3): 481-510.

Granovetter, M. (1992), "Problems of explanation in economic sociology'. In: Nitin, N. \& Eccles, R.G. (Ed), Networks and Organisations; Structure, Form, and Action. Harvard Business School Press, Boston. pp. 25-56.

Gravier, M. J. and Swartz, S. M. (2009), The dark side of innovation: Exploring obsolescence and supply chain evolution for sustainment-dominated systems. The Journal of High Technology Management Research, 20(2): 87-102.

He, J. J. and Tian, X. (2013), The dark side of analyst coverage: The case of innovation. Journal of Financial Economics, 109(3): 856-878.

Hedström, P., \& Wennberg, K. (2016). Causal mechanisms in organization and innovation studies. Innovation, pp. 1-12.

Hemlin, S, Allwood, C., Martin, B. and Mumford, M. (2014). Creativity and Leadership In Science, Sechnology, and Innovation. London, Routledge.

Hitt, M. A. and Ireland, R. D. (2002), "The essence of strategic leadership: managing human and social capital", Journal of Leadership and Organizational Studies, 9:3-14.

Howell, J. M. and Boies, K. (2004), Champions of technological innovation: The influence of contextual knowledge, role orientation, idea generation, and idea promotion on champion emergence. The Leadership Quarterly, 15(1):123-143.

Hurt, C. (2009), "Evil has a New Name (and a New Narrative): Bernard Madoff" Michigan State Law Review, Michigan, pp. 947-987.

Jagpal, N. and Craig, J. (2009), "Learning from Madoff: Lessons for foundations Boards." National Committee for Responsive Philanthropy.

Hung, K. and Chou, C. (2013), "The impact of open innovation on firm performance: the moderating effects of internal R\&D and environmental turbulence", Technovation, 33(10-11): 368-380.

Johannessen, J., Olsen, B., and Lumpkin, G. (2001), "Innovation as newness: what is 
new, how new, and new to whom?", European Journal of Innovation Management, 4(1): 20-31.

King, N. and Horrocks, C. (2010), Interviews in Qualitative Research, Sage.

Lee, R. (2008), "Social capital and business and management: Setting a research agenda", International Journal of Management Reviews, 10(3):1-27.

Lewis, L. S. (2012), Con Game: Bernard Madoff and his Victims, New Brunswick, London.

Lin, N. (1999), "Social Networks and Status Attainment', Annual Review of Sociology, 25: 467-487.

Lin, N. (2001), Social Capital, A Theory of Social Structure and Action, Cambridge University Press, Cambridge.

Mackay, C. (1852/1995), Extraordinary Popular Delusions and the Madness of Crowds, Wordsworth Reference, Hertfordshire.

MacKay, M. (2013), Impeccable Connections: The Rise and Fall of Richard Whitney, Black Tower Press, New York.

Madoff, R. (1996), The Great Chefs of America Cook Kosher, Vital Media Enterprises, New York.

Markides, C. (2006). Disruptive innovation: In need of better theory. Journal of Product Innovation Management, 23: 19-25.

Marques, J. (2014), “Closed versus open innovation: evolution or combination?, International Journal of Business and Management, 9(3): 196-203.

Mathews, M. and Stokes, P. (2013), The Creation of Trust - The Interplay of Rationality, Institutions and Exchange, Entrepreneurship and Regional Development 25(9-10): 845-866.

Martinez-Conesa, I., Soto-Acosta, P., and Carayannis, E. G. (2017), On the path towards open innovation: Assessing the role of knowledge management capability and environmental dynamism in SMEs. Journal of Knowledge Management, 21(3): 553-570.

Miglietta, N., Battisti, E., and Garcia-Perez, A. (2018), Shareholder value and open innovation: evidence from Dividend Champions. Management Decision.

https://doi.org/10.1108/MD-04-2017-0408

Molina-Morales, F. X., Martínez-Fernández, M. T., and Torlò, V. J. (2011), The dark side of trust: The benefits, costs and optimal levels of trust for innovation performance. Long Range Planning, 44(2): 118-133.

Möllering, G. (2006), Trust: Reason, Routine, Reflexivity. Bingley, Emerald Group Publishing. 
Nahapiet, J. and Ghoshal, S. (1998), "Social capital, intellectual capital and the organizational advantage", Academy of Management Review. 23(2): 242-266.

Nars, K. (2009), Swindling Billions, Marshall Cavendish, London.

Nash, R., Bouchard, M. and Malm, A. (2013), "Investing in people: The role of social networks in the diffusion of a large scale fraud." Social Networks, 35(4): 686-698.

Natalicchio, A., Ardito, L., Savino, T., and Albino, V. (2017), Managing knowledge assets for open innovation: a systematic literature review. Journal of Knowledge

Management, 21(6): 1362-1383.

Newburn, T. (2007), Criminology. Cullompton, Willan.

Noordhoff, C. S., Kyriakopoulos, K., Moorman, C., Pauwels, P., and Dellaert, B. G. (2011), The bright side and dark side of embedded ties in business-to-business innovation. Journal of Marketing, 75(5): 34-52.

Pastoriza, D., Arino, A. and Ricart, J.E. (2008), Ethical managerial behaviour as an antecedent of organisational social capital, Journal of Business Ethics, 78:329-341.

Payne, P. (2012), White Collar Crime, The Essentials, Sage, London.

Perri, F. S. and R. L. Brody, (2011), "Birds of the same feather: The dangers of affinity fraud." Journal of Forensic Studies in Accounting and Business, 10(3):33-46.

Polanyi, K. (1944/2001), The Great Transformation. ( $2^{\text {nd }}$ Ed), Beacon Press, Boston.

Ponzi, C. The Rise of Mr Ponzi. Accessed 23 February 2015. http://pnzi.com/

Portes, A. (1998), 'Social capital: Its origins and applications in modern sociology', Annual Review of Sociology, 24: 1-24.

Portes, A. and Sensenbrenner A. (1993), "Embeddedness and immigration: Notes on the social determinants of economic action", American Journal of Sociology, 98:1320-1350.

Putnam, R. D. (1993), Making Democracy Work. Civic Traditions in Modern Italy, Princeton University Press, Princeton.

Putnam, R. D. (2000), Bowling Alone, Simon Schuster, New York.

Putnam, R. D. (2004), "Using social capital to help integrate planning theory, research and practice”, Journal of American Planning Association, 70:142-192.

Prusak, D. and Cohen, L. (2001), In Good Company, Boston. Harvard Business School Press. Harvard.

Reed, T.E. (2007), 'Affinity Fraud', available at:

http://colonendparenthesis.blogspot.com/2007/05/affinity-fraud-by-trevor-e-reed.html

Runyan D. (1992), Guys and Dolls: The Stories of Damon Runyan, Penguin, New York. 
Saleh, H. G. A and Hu, W. (2016), Dark Side of Leadership Impact on Project Failure: Towards a Model. Innovation and Management, 1814: 936-939.

Shibutani, T. (1955), "Reference Groups as Perspectives", in Manis, J.G. and Meltzer, B.N., ( ${ }^{\text {rd }}$ Ed), Symbolic Interaction: A Reader in Social Psychology, Allyn and Bacon, Massachusetts, Massachusetts, pp. 105-115.

Schoenheimer, I., MacNeil, K. and Madoff, R. (1996), The Great Chefs of America Cook Kosher, Vital Media Enterprises, New York.

Schonsheck, J. (2000), "Business friends: Aristotle, Kant and other management theorists on the practice of networking", Business Ethics Quarterly, 10(4): 897-910.

Siggelkow, N. (2007), Persuasion with case studies, Academy of Management Journal, 50: $20-24$.

Silverman, D. (2011) Qualitative Research, London, Sage Publications.

Sol, J., Beers, P. J., and Wals, A. E. (2013), Social learning in regional innovation networks: trust, commitment and reframing as emergent properties of interaction. Journal of Cleaner Production, 49:35-43.

Somaiya, R. (2010), 'Bernie Behind Bars: Madoff's Plush Prison Life'. Newsweek, $7^{\text {th }}$ June Smith, G, M Button, L. Johnnston and K. Frimpong, (2001), Studying Fraud as White Collar Crime, Palgrave Macmillan, London.

Stokes, P. (2016), 'Chapter 2: Historical and Contemporary Contexts: The Representation and Character of 'Modern' Organizations', Stokes, P., Moore, N., Smith, S., Rowland, C. and Scott, P (2016) Organizational Management. London. Kogan Page, pp. 27-45.

Vanity Fair April 2009, available at: www.vanityfair.com/news/2009/.../bernard-madoff,

Van Oudheusden, M. (2014), Where are the politics in responsible innovation? European governance, technology assessments, and beyond. Journal of Responsible Innovation, 1(1): 67-86.

Ventura, M., and Daniel, S. J. (2010), 'Opportunities for fraud and Embezzlement in Religious Organizations: An Exploratory Study', Journal of Forensic \& Investigative Accounting, 2(1): 1-35.

Walker, P. (2008), "Putting social capital to work”, Business History, 50(6): 685-694.

Wang, Y., Guo, B., and Yin, Y. (2017), Open innovation search in manufacturing firms: the role of organizational slack and absorptive capacity. Journal of Knowledge

Management, 21(3): 656-674.

Woolcock, M. (2001), "Microenterprise and social capital: A framework for theory, research, and policy", Journal of Socio-Economics, 30:193-198. 
Worsnop, T., Miraglia, S., \& Davies, A. (2016). Balancing Open and Closed Innovation in Megaprojects: Insights from Crossrail. Project Management Journal, 47(4):79-94.

Zuckoff, M. (2005), Ponzi's Scheme, Random House, New York. 